\title{
HISTORICAL TOPICS IN ENGLISH LANGUAGE TEXTBOOKS AS A PART OF CULTURAL LITERACY
}

\author{
Peter Mikulas - Alena Mikulasova
}

\section{doi: 10.18355/PG.2016.5.2.232-245}

\begin{abstract}
Abstact
The following paper deals with the cultural aspects in teaching English as a foreign language. It describes the current state of knowledge in this field claiming that foreign language education means more than a linguistic preparation. Teaching of foreign languages helps to shape personalities of learners and should develop the intercultural competence as well. Using quantitative analysis, we focused on a sample of three currently used textbooks intended for teaching English as foreign language at Slovak schools and the representation of historical topics. Attention was paid to historical period, geographical region and historical approach. This paper might be a starting point for further research on cultural aspect in English language textbooks and a basis for following qualitative analysis.
\end{abstract}

\section{Key words}

textbooks, culture in EFL, quantitative analysis, history

\section{Introduction and literature review}

In available literature, various definitions of a textbook may be found. Solaiman (2007: 433) defines it as a book aimed for instructional purposes, especially in schools and colleges. The Greenwood dictionary of Education defines textbook as "... a book used in a particular branch of study. Textbooks are most often used to assist the teacher in content area subjects, including social studies, science, language arts, and mathematics. Effective textbooks assist students through the use of text organizes, pattern guides, and glossaries" (Collins - O'Brien, 2011: 464). Some experts understand the term textbook even broader and they use this category for various teaching materials as well (CDs, internet, video, etc.) (Johnsen, 2001: 50; Petrikova, 2014). The common feature of textbook is the educational purpose. In our paper, a textbook is understood as a book intended for teaching English as a foreign language. Even the usage of new technologies has not stopped the demand for textbooks (Garinger, 2002: 1). The use of textbooks still prevails; they have many advantages but also disadvantages (Lassig, 2009; Klerides, 2010; Borhaug, 2014). Therefore they are repeatedly the object of research and a topic for scientific studies. Patricia Byrd (2001: 415) claims that most teachers depend on textbooks they use, because they provide content and activities that shape what happens in the classroom. That is the reason why it is important to pay enough attention not just to linguistic content, but also to "cultural" content of recommended textbooks.

Currently, as a response to globalisation trends, and recommendation of international organisations, governments pay more attention to foreign 
language education. In many countries in the world English as a foreign language is almost synonymous with foreign language learning (Byram, 2008: 9). In Europe, foreign language education belongs to one of the priorities of European Union (Key data on Teaching Languages at School in Europe, 2012: 7). In the last decades there was a discussion about goals of foreign language education and about expectations resulting from foreign language teaching (Birova - Eliasova, 2014).

Foreign language learning provides not just linguistic preparation, but it has far wider impact. Languages help to shape personalities of learners. The common European framework for reference of languages indicates that it “... is a central objective of language education to promote the favourable development of the learner's whole personality and sense of identity in response to the enriching experience of otherness in language and culture" (CEFR, 2006: 1). The aims are more complex and researchers in previous decades distinguished several competences that may be developed by foreign language education. Hymes in 1972 introduced the term communicative competence (Celce-Murcia, 2007: 41). In following years the term has been repeatedly discussed and redefined by many authors. Frequently found is the division of communicative competence into grammatical, discourse, sociolinguistic and strategic competence (Canale - Swain, 1980: 1-47). This division was elaborated and modified in early 1990s' (Gomez-Rodriguez, 2010: 329-330; Celce-Murcia, 2007; Kramsch, 2013: 69-70). Later, Michael Byram introduced the term intercultural communicative competence. The change in understanding the role of culture in foreign language education is obvious. The terms of cultural and intercultural competence are often used interchangeably (especially in documents produced by political agencies), but the meaning of intercultural competence is wider, including also the effort to increase dialogue and cooperation between different national cultures (Kramsch, 2013: 69; Reid, 2014). Culture is not an extra skill, but it should be taught together with other skills (Reid, 2012: 194). Authors of textbooks should use a high level of creativity to offer balanced informing about various aspects of culture, but also to be competitive on the contemporary textbooks market (Fichnova - Wojciechowski - Szabo, 2012).

Central European framework for reference of languages prepared by Council of Europe distinguishes between linguistic and cultural competence in foreign language education. Teaching and learning of foreign language develop not just the linguistic competence of learners, but cultural competence as well. However, the "cultural competence" is sometimes misunderstood in school praxis. The aim should not lie only on pressure to memorise and remember geographical, historical and cultural facts about countries, where the target language is used, but also to understand and respect wider contexts and cultures. The important part of cultural competence is the intercultural awareness, defined as “... knowledge, awareness and understanding of the relation (similarities and distinctive differences) between the 'world of origin' and the 'world of the target community... it includes an awareness of regional and social diversity in both worlds“ (CEFR, 2006: 103). 
Byram (1993: 5-10) focuses on the cultural aspect of education, especially in foreign language education. He distinguishes eight areas of cultural content in textbooks. Byram's division is comprehensive and useful in terms of research practice. It covers almost every aspect of the culture. His outcomes were chosen as the basic theory for following research that will analyse and evaluate the data connected to the sixth point of Byram's division (National history) and last added part of culture National culture heritage in selected textbooks. The criterion of National history in his division is too specific for research purposes. In further texts it is understood as history in general, more concretely as topics related to history, usually understood as older than 30 years.

Various aspects of the representation of historical topics in school textbooks was investigated by many scholars, including Morgan, 2014; Foster, Burgess, 2013; Korytnikova, 2013; Morgan, Henning, 2013 and others. History is with no doubt an important part of culture and of cultural heritage. As Delgadová (2011: 37) states, history is particularly important element of culture and it is crucial to distribute it to society on various levels (Palarik, Eliasova, 2012). Therefore it is justified to search for historical topic and their presentation in textbooks. Furthermore, it is crucial for all citizens in democratic countries to be familiar with history, because it is central humanistic discipline and it helps to build active citizenship. History provides the space for creating and expressing of opinions, looking for causes, consequences and solutions and it is a gateway to other humanistic

234 disciplines. Well-taught history has great potential in understanding and respecting "otherness", different traditions and cultures. In this sense it is one of the key subject to build intercultural competence. History is an independent school subject and within the area of world history, students get familiar also with the history of English speaking countries. From this point of view, it may be understood as useless duplicity. But to understand history and create intercultural competence this way would be an inappropriate simplification. Except for vocabulary and linguistic competence, historical topics taught in foreign language provide other points of view, different opinions and understanding of historical events and personalities. That is one of the possible ways how to reach the multiperspectivity toward a historical topic (Stradling, 2004). This approach allows seeing history and traditions more balanced than the traditional "flat" national point of view can provide. In the framework of Slovak national curriculum for English, history is mentioned repeatedly, e.g. as one of the topics suitable for development of communicative skills. More concretely, the curriculum mentions historical monuments, history of Slovakia, history of target language (national curriculum English language B1: 42, 55, 58). This characteristic is very wide and provides sufficient platform for teachers' creativity.

\section{Research}

Textbooks are repeatedly subjected to research, interpretation, analysis and comparison. Various methods are applied in textbook research. The methodology used in this paper is based on the content analysis. Content 
analysis is a research method for studying of the content of written (visual), heard (audial) or seen (audio-visual) data (Wimmer - Dominick, 2011: 156 157). While applying a content analysis, the researcher can analyse different kinds of media, such as books, articles, diaries, letters, interviews, speech, dialog, reports and literarily all material that has been created from any media. Content analysis can be applied in order to get a general and summarised description of any media presented phenomenon. According to Hesmondhalgh (2006: 138) the tradition of content analysis can be tracked down to sociology and especially to journalism, but soon it has spread to many other disciplines including pedagogy (Gavora 2000: 117 - 122). Nowadays, content analysis is very popular research method in many subjects, such as history, advertising, communication, linguistics, psychology, anthropology, political science, politics, cultural studies and it can be even used in some others.

Pingel (2010: 66) describes two basic possible research approaches to textbook research: quantitative and qualitative analysis. It is crucial to accept, however, that these approaches give us answers on different questions. Both of them have pros and cons. Quantitative analysis measures frequency and determine how many times event, person, country, topic etc. is mentioned and how much space is given to defined categories. It is necessary to be aware of the cons of this method as it "... can tell us a great deal about where the emphasis lies and about selection criteria, but nothing about values and interpretation" (Pingel, 2010: 66). This method can provide important and valuable data for further interpretation as well as for qualitative analysis.

Qualitative analysis deals with assumptions that cannot be measured. It applies less strict research methods, which rely more on the reviewer's own value system and understanding of the text itself (Pingel, 2010). This method explains the way that the information is presented in the text. There are various approaches to the qualitative research as hermeneutic analysis, linguistic analysis, cross-cultural analysis or discourse analysis. Mentioned methods accompany each other and complement each other. However, Pingel (2010) did not mention further methods of qualitative analysis such as visual analysis, semiotic analysis, question analysis etc. These were not incorporated in first nor in second edition of his handbook of textbook research (Nicholls, 2003: 4). Interesting, contribution to discussion concerning research methodology was brought by J. Nicholls (2005: 24 - 35). Some authors (Bertran - Hughes, 2006; Trampota - Vojtechovska, 2010) recommend using mixed type of content analysis, which is called qualitativequantitative. Content analysis is helpful tool for identification of certain topics in media content. For this purpose it is necessary to set criteria for analysis and unit of analysis.

The following research conducts quantitative analysis of chosen textbooks intended for teaching English as foreign language in Slovak republic. All of them are currently used in courses in Slovak schooling system, namely New Opportunities, Real Life and Success. In all cases they are pre-intermediate level of textbooks, intended for B1 proficiency. The research unit for purposes of following research is defined as an article or thematic area in the selected textbook intended for pre-intermediate students (New Opportunities, 
Success, Real life) containing historical topics, including related exercises. Secondary, observed was the presence of photographs or other visual sources contained in the research unit that are understood as integral part of the text. For the purposes of our research we set three research questions:

1. What is the representation of thematic circuits containing historical topics?

2. What are the main historical topics in the analysed textbooks?

3. What kind of historical approach prevails in particular textbooks?

Based on research questions, we set following hypotheses:

It is assumed that particular historical periods will be represented equally in selected textbooks.

Textbooks will focus on history of the countries, where the target language is used. Our assumption is partly based on hypothesis no. 2, which expects overwhelming focus of researched textbooks on history of English speaking countries. History of the English speaking countries, especially of the United Kingdom (around the $18^{\text {th }}-19^{\text {th }}$ century also of the United States and partly other countries Canada, Australia, New Zealand and others) is undoubtedly significant in terms of a global context and it represents long time period. Since the United Kingdom and later the United States were important world powers for a long time, we expect that the authors of textbooks will reach for 236 a wide range of topics related to the history, from ancient times through the Middle Ages to Modern Ages and Modern history. We also expect that some research units will be focused on more than one topic from different historical periods. For such cases we decided to create a subcategory others, which will be used if there will be more than 2 historical periods presented in single research unit. Further subcategories are: until $1500 ; 16^{\text {th }}-18^{\text {th }}$ century; $19^{\text {th }}$ century; $1900-1950$ and $1950-1990$.

It is assumed that the textbooks will pay most of the attention to the history of the countries, where target language is official language (United Kingdom, United States, Canada, Australia, New Zealand, various African states etc).

Partial aim of foreign language education is teaching culture, which includes the explanation of life, traditions and culture of countries where the target language is used. It can therefore be assumed that crucial criterion for historical topics will also include familiarity with the history of these countries, primarily the United Kingdom (where textbooks are prepared) and the United States, followed by the other English speaking countries. At the same time we expect little interest of textbooks on historical topics outside of the English speaking countries. For other countries, including Europe, we designed subcategory rest of the world. For the cases of an overlapping between the countries, we will include all the geographic areas covered by the research unit into the content analysis. Further subcategories are: United Kingdom; United States; Other English speaking countries; Rest of the world. 
It is assumed that political history and the history of everyday life will be the most frequented categories in terms of historical approach.

Political history is one of the most frequent historical approaches in content of teaching the subject history. Therefore this study assumes this also will be the case in English language textbooks it will be crucial to include topics and terminology of political history. The popular approach to history is presented by so called history of everyday life, so we assume that also these topics will be included. We expect only minor presence of other approaches defined in subcategories: economic history; history of art and literature and history of science and inventions.

Overall results of content analysis are presented in table 1.

Table 1: Overall results

\begin{tabular}{|c|c|c|c|c|c|c|c|c|c|c|c|c|c|c|c|}
\hline Overall r & ults & & & & & & & & & & & & & & \\
\hline \multirow[b]{2}{*}{ Topic } & \multicolumn{6}{|c|}{ Historical period } & \multicolumn{4}{|c|}{$\begin{array}{l}\text { Geographical } \\
\text { region }\end{array}$} & \multicolumn{5}{|c|}{ Historical approach } \\
\hline & $\begin{array}{l}8 \\
\stackrel{2}{1} \\
\bar{\Xi} \\
5\end{array}$ & 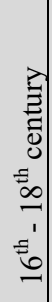 & 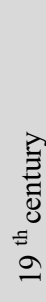 & 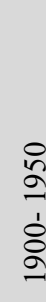 & $\begin{array}{l}\frac{8}{2} \\
\frac{1}{2} \\
\stackrel{2}{\alpha}\end{array}$ & $\frac{\tilde{\Xi}}{\tilde{\Xi}}$ & 光 & $\begin{array}{l}\varangle \\
\mathscr{2} \\
ٌ\end{array}$ & 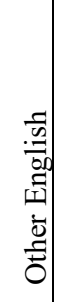 & 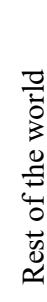 & 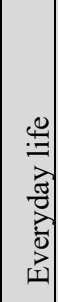 & 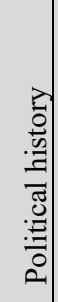 & $\mid \begin{array}{r}2 \\
0 \\
.02 \\
. \pm \\
.0 \\
.0 \\
0 \\
0 \\
0 \\
0 \\
.1 \\
0\end{array}$ & 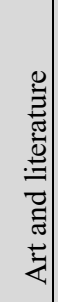 & 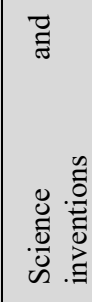 \\
\hline $\begin{array}{l}\text { New } \\
\text { Opportu } \\
\text { nities }\end{array}$ & 0 & 2 & 3 & 5 & 3 & 2 & 6 & 7 & 1 & 4 & 4 & 1 & 0 & $\begin{array}{l}1 \\
0\end{array}$ & 1 \\
\hline Success & 0 & 3 & 1 & 4 & 4 & 4 & 8 & 8 & 1 & 9 & 4 & 1 & 1 & 6 & 6 \\
\hline Real Life & 0 & 0 & 1 & 2 & 4 & 1 & 3 & 4 & 0 & 2 & 1 & 2 & 0 & 4 & 2 \\
\hline Together & 0 & 5 & 4 & $\begin{array}{l}\mathbf{1} \\
\mathbf{1}\end{array}$ & $\begin{array}{l}1 \\
1\end{array}$ & 7 & $\begin{array}{l}1 \\
7\end{array}$ & $\begin{array}{l}1 \\
9\end{array}$ & 2 & $\begin{array}{l}1 \\
5\end{array}$ & 9 & 4 & 1 & $\begin{array}{l}2 \\
0\end{array}$ & 9 \\
\hline
\end{tabular}

While discussing the category Historical period (Fig. 1.), the first surprising result was almost complete absence of history covering the period before the $15^{\text {th }}$ century. It is even more surprising when we consider the fact that this subcategory covers the longest time period in the research as compared to the other subcategories. Ancient and medieval period included frequent topics in the curriculum of subject History and British history provides numerous attractive topics (e.g. first settlers, Celts, Norman kings etc.). Prior mentioned exceptions were represented by texts that went beyond the defined time frame and covered large time period. An example might be found in the textbook Success, where the text "Was Fred Flintstone a vegetarian " (Success: 53) was dedicated to eating habits, while the small proportion of text was devoted to the prehistoric period. According to the described research procedure, this unit was classified into the subcategory Others, despite such broad understanding of the subcategory. Until 1500, we identified only minor representation of topics. 


\title{
Historical period
}

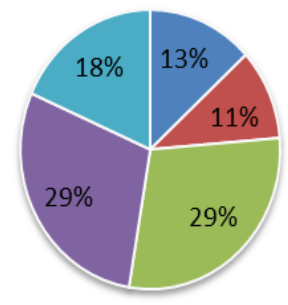

\author{
16th -18th century \\ 19th century \\ 1900- 1950 \\ — 1950-1990 \\ Others
}

\section{Figure 1: Historical period coverage in selected English language textbooks}

Category $16^{\text {th }}-18^{\text {th }}$ and $19^{\text {th }}$ century were represented at about the same rate (13\%: 11\%). In this case, authors included topics of defined time periods at around the same range. For these two categories, results are in accordance with the second hypothesis.

From a quantitative point of view, most units were dedicated to the $20^{\text {th }}$ century. For better clarity we decided to divide this period to its first and second half. The twentieth century clearly devoted most attention to history with together up to $58 \%$ of the research units within this time period. In some cases, the research unit exceeded the specified time intervals and addressed the entire $20^{\text {th }}$ century. In such cases, the research unit was included into each defined subcategory. This fact partly affected the final high percentage of $20^{\text {th }}$ century topics. Nevertheless, the dominance of the Modern History topics is clear and disproportionate in relation to other defined time periods. Hypothesis 1 was not confirmed. Researched textbooks did not address defined time periods proportionally with exception of categories 16th-18th and 19 th century. The time period of the 20 th century clearly dominates in all studied textbooks. The striking differences between the textbooks in this category were not observed.

Interesting results were also brought by the category named Geographical region (Fig. 2). Examined textbooks are all produced by prestigious British publishers and were written by British authors. Considering this fact we expected significant emphasis on the topics related to the history of the United Kingdom. Surprisingly, this assumption was not confirmed. Summary results showed small majority of topics related with the United States, although the difference between the U.S. and UK was not particularly significant (36\%: 32\%). Therefore, the sampled textbooks had a relatively balanced representation of historical topics related to the U.S. and UK. 


\section{Geographical region}

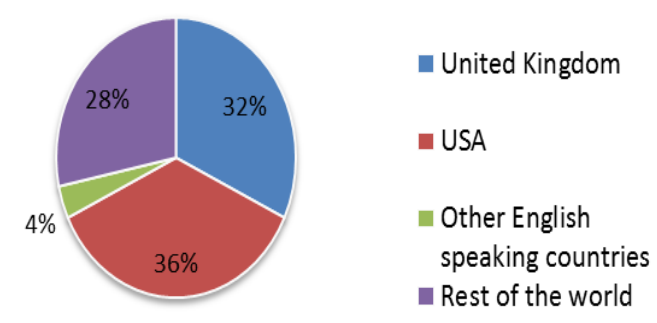

\section{Figure 2: Geographical region coverage in selected English language textbooks}

Another interesting result is that the history of other English speaking countries was represented only sporadically. For example, in the textbook Real Life we could not identify any unit of analysis related to the history of another English speaking country. In two other textbooks we identified only one topic partially related to other English speaking countries in each. New Opportunities in topic campaigners introduced also Mother Teresa connected to India, where English is official language and Nelson Mandela was connected to South Africa. Textbook Success mentioned Fred Flintstone a vegetarian regarding Aborigines in Australia, but it was just marginal reference.

Unexpectedly, we observed significant percentage of topics geographically related to the rest of the world. Similarly to the U.S. and UK, the rest of the world was represented by around one third of research units $(28 \%)$. Topics related to the rest of the world were various. Introduced were personalities (Václav Havel, Pablo Piccasso, Wassily Kandinski, Camille Pissarro, Heinrich Tyssen and others) as well as events connected to countries where English is not an official language (history of European integration, eruption on the island Krakatoa in Indonesia, history of Eurovision song contest).

Hypothesis 2 was not confirmed. The history of United Kingdom was not dominant in the sampled textbooks. We identified relatively proportionally representation of topics focused on the history of the UK, U.S. and rest of the world. Only very little space was devoted to other English speaking countries. Surprising results emerged also in the category named Historical Approach (Fig. 3). The most frequent topic was a History of art and literature, which was covered by nearly half of the research units (47\%). History of art and literature dominated in all textbooks included in the survey sample. These themes especially dominated in New Opportunities, where there were texts and information with historical context dedicated to concrete British and American writers (e.g. William Shakespeare, John Steinbeck, Edgar Allan Poe, Oscar Wilde). The textbook Success offered information and historical contexts to Agatha Christie, Samuel Taylor Coleridge, usually accompanied with samples of their works. Also other types of art history such as music, visual art and film were identified. 


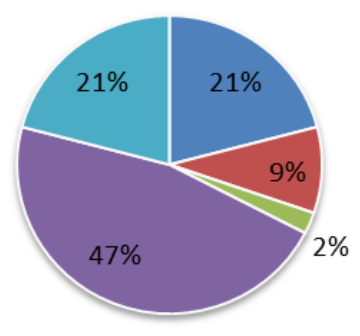

\title{
Historical approach
}

\author{
Everyday life \\ Political history \\ Economic history \\ History of art and literature \\ History of science and inventions
}

\section{Figure 3: Historical approach identified in selected English language textboos}

The same percentage (21\%) referred to subcategories history of science and inventions and the history of everyday life. History of science and inventions was presented by topics like e.g. invention of TV and penicillin (Success) History of everyday life had a significant presence, albeit not as dominant as predicted in the hypothesis and was covered by various topics.

We also identified rather rare representation of topics addressing political history. We identified only $9 \%$ of such topics, making political history a de facto boundary theme. As part of the political history we considered topics categorized as Campaigners (New Opportunities) where were discussed the human rights and politics of passive resistance or European integration (Success). The theme economic history, however, was totally marginalized, as we identified the only one research unit devoted to this historical approach (Success). The most frequent approach to history in researched textbooks was found in the categories of history of arts and literature and history of science and inventions. History of everyday life did not occur to the extent as expected and political history was present only marginally. For these reasons we conclude that hypothesis no. 3 was not confirmed.

\section{Discussion}

Culture is integral part of everyday life. People are exposed to various cultural impulses on daily basis. Therefore it is necessary to pay attention to cultural content incorporated in whole range of artefacts, including school subjects, especially school subjects with a focus on humanities as they offer a wide space for teaching culture and developing of intercultural competence. These are important competencies regarding foreign language education.

As for the geographical region, we identified equal proportional representation of the history of the United Kingdom and the United States. History of other English speaking countries was incorporated marginally. A particularly interesting was in the significant omission of other countries where English is an official language. In this case, further research and addition of other textbooks covering various stages of language proficiency, 
could show, whether and what kind of information students may obtain about other English speaking countries during English lessons.

Although political history currently presents the main approach in teaching history, this statement is not valid for research sample. Also topics related to economic history were found only marginally. On the other hand, the most frequented topics are related to the history of art and literature. Students are introduced to selected literature authors from British Islands and United States, provided some biographical information, historical contexts as well as samples of their works. Other arts are also represented, including dance, music and visual arts. We identified an average representation of articles related to history of everyday life.

A particularly interesting result of this content analysis was the almost total absence of historical topics connected with the events older than 1500 . Additionally, topics covering $16^{\text {th }}$ and $17^{\text {th }}$ century were rather rare. On the other hand, we identified a predominance of topics related to the $20^{\text {th }}$ century. Events of the last century might be considered very attractive for students perhaps because they have extraordinary possibilities for visual processing. The most important reason why these topics are predominantly represented might be also lie in the assumption that they still have significant impact on the current political and economic situation as well as on everyday life. Therefore, it is reasonable to discuss topics related to $20^{\text {th }}$ century in extended way.

\section{Conclusions}

Topics with historical background represent significant part of culture on national as well as on international level. Therefore it is justified that they are presented in textbooks intended for foreign language education. In our research, we found that these topics are quite frequent, and there is no doubt that textbooks shape linguistic, and the cultural competence of readers. The research showed what kinds of topics prevail in current textbooks, but also pointed to the thematic areas, which are rare or completed omitted. In some aspects the compared textbooks were very similar, but in other respects we identified a relatively large differences.

In the light of the results, however, we may consider that representation of topics in history may be globally consistent. It can be stated that in the textbooks of English more recent historical themes predominate earlier ones, and the dominant emphasis is clearly placed on the 20th century. In connection with the category Geographic region, we found that the Englishspeaking world is depicted in textbooks as the USA and Great Britain, and other countries where English is used as an official language are rather marginalized. The approach to historical topics generally is focused on art and literature, less on everyday life and science. Other approaches are almost missing. In this context, we could apply broader concepts explaining the functioning of educational and information media, such as priming, framing and agenda setting. Further research based on qualitative analysis of obtained data could bring other interesting results and show further possible approaches of content analysis of textbooks used in foreign language education. 


\section{Bibliographic references}

BERTRAN, I. - HUGHES, P. 2005. Media Research Methods. Audiences, Institutions, Texts. Basingstoke: Palgrave MacMillan. ISBN 9780333960943. BIROVA, J. - ELIASOVA, S. 2014. Plurilingual and Pluricultural Competence and Foreign Language Teaching at Primary and Secondary Schools in Slovakia. In: Xlinguage, vol. 7, n. 1. ISSN 1337-8384.

BØRHAUG, K. 2014. Selective critical thinking: A textbook analysis of education for critical thinking in Norwegian social studies. In: Policy Futures in Education, vol. 12, n. 3, pp. 431- 444. ISSN 1478-2103.

BYRAM, M. 1993. Language and Culture Learning: The Need for Integration. In: BYRAM, M. (ed.). Germany, its Representation in Textbooks for Teaching German in Great Britain. Frankfurt am Main: Diesterweg, pp. 3 16. ISBN 978-3883042749.

BYRAM, M. 2008. From Foreign Language Education to Education for Intercultural Citizenship. Essays and Reflections. Clevedom: Buffalo: Toronto: Cromwell Press. ISBN 978-1-84769-079-1.

BYRAM, M. - MORGAN, C. et al. 1994. Teaching and Learning Language and Culture. Cleredon: Multilingual Mattes. ISBN 1-85359-212-9.

BYRD, P. 2001. Textbooks: Evaluation for selection and analysis for implementation. Teaching English as a Second or Foreign Language. In:

242 CELCE-MURCIA, M. (ed.) Teaching English as a second or foreign language. Boston: Heinle \& Heinle. ISBN 0-8384-1992-5.

CANALE, M. - SWAIN, M. 1980. The Theoretical Bases of communicative approaches to second language teaching and testing. In: Applied Linguistics, vol. 1, n. 1, pp. 1-47. ISSN 0142-6001.

CELCE-MURCIA, M. 2007. Rethinking the Role of Communicative Competence in Language Teaching. In: SOLER, E. A. - JORDA M. S. (eds.). Intercultural Language Use and Language Learning. Dordrecht: Springer, pp. 41-57. ISBN 978-1-24020-5636-9.

COLLINS, W. J. - O'BRIEN, N. P (eds.). 2011. The Greenwood Dictionary of Education. Greenwood: ABC-Clio. ISBN 978-0-313-37930-7.

Common European Framework of Reference for Languages (CEFR). 2001. ISBN 978-0-521-80313-7.

DELGADOVA, E. 2011. Struktura kultury a kulturne odlisnosti. In: Lingua Summit 2011: Problemy vzdelavania v kontexte sucasnosti. Trencin: TnUAD, pp. 36-40. ISBN 978-80-8075-517-1.

FICHNOVA, K. - WOJCIECHOWSKI, L. - SZABO, P. 2012. Originalita plagiatu - plagiatorstvo originality. The Originality of Plagiarism - the Plagiarism of Originality. In: Annales Universitatis Paedagogicae Cracoviensis: Studia Linguistica VII. Dialog z tradycja, vol. 115, n. 7, part 2, pp. 106-115. ISSN 2083-1765.

FOSTER, S. - BURGESS, A. 2013. Problematic portrayals and contentious content: Representations of the Holocaust in English history textbooks. In: 
Journal of Educational Media, Memory and Society, vol. 5, n. 2, pp. 20-38. ISSN 2041-6938.

GARINGER, D. 2002. Textbook selection for the ESL Classroom. [cit. 15.08.2014] Available online: $<$ http://www.cal.org/resources/digest/digest_pdfs/0210garinger.pdf $>$

GAVORA, P. 2000. Uvod do pedagogickeho vyskumu. Brno: Paido. ISBN 80-85931-79-6.

GOMEZ-RODRIGUEZ, L. F. 2010. English Textbooks for Teaching and Learning English as a Foreign Language: Do They Really Help to develop Communicative Competence? In: Educación y educadores, vol. 13, n. 3, pp. 327-346. ISSN 0123-1294.

HESMONDHALGH, D. 2006. Discourse Analysis and Content Analysis. In GILLESPIE, M. - TOYNBEE, J. (eds.). Analysing Media Texts. Open University Press, pp. 119-156. ISBN 0-335-21887-3.

JOHNSEN, E. B. 1993. Textbooks in the Kaleidoscope. A Critical Survey of Literature and Research on Educational Texts. Oxford: Oxford University Press. ISBN 82-00-21506-7.

Key data on Teaching Languages at School in Europe. 2012. ISBN 978-929201-273. [cit. 12.7.2014] Available online: $<$ http://eacea.ec.europa.eu/education/eurydice/documents/key_data_series/14 3EN.pdf>

KLERIDES, E. 2010. Imagining the textbook: Textbooks as discourse and genre. In: Journal of Educational Media, Memory, and Society, vol. 2, n. 1, pp. 31-54. ISSN 2041-6938.

KORYTNIKOVA, N.V. 2013. On methods of assessing tolerance while narrating history in textbooks. Sotsiologicheskie Issledovaniya, n. 4, pp. 4252. ISSN 0132-1625.

KRAMSCH, C. 2013. Culture in Foreign Language Teaching. In: Iranian Journal of Language Teaching Research, vol.1, n. 1, pp. 57-78. ISSN 23221291.

LÄSSIG, S. 2009. Textbooks and beyond: Educational media in context(s). In: Journal of Educational Media, Memory, and Society, vol. 1, n. 1, pp. 1-20. ISSN 2041-6938.

MORGAN, K. 2014. Decoding the visual grammar of selected South African history textbooks. In: Journal of Educational Media, Memory, and Society, vol. 6, n. 1, pp. 59-78. ISSN 2041-6938.

MORGAN, K. - HENNING, E. 2013. Designing a tool for history textbook analysis. In: Forum Qualitative Sozialforschung, vol. 14, n. 1. ISSN 14385627.

National Curriculum of English Language, B1. 2012. [cit. 15.9.2014] Available online: $<$ http://www.statpedu.sk/files/documents/svp/gymnazia/vzdelavacie_oblasti/a nglicky_jazyk_b1_titul.pdf>

NICHOLLS, J. 2003. Methods in School Textbook Research. In: International Journal of Historical Learning, Teaching and Research, vol. 3, n. 2, pp. 11-26. ISSN 1472-9466. 
NICHOLLS, J. 2005. The Philosophical Underpinnings of School Textbook Research. In: Paradigm: Journal of the Textbook Colloquium, vol. 3, n. 1, pp. 24-35. ISSN 0966-8292.

PALARIK, M. - ELIASOVA, S. 2012. Distribucia kulturneho odkazu v muzejnej institucii s dorazom na sucasne trendy - vystava "Mesto pod mestom" v Ponitrianskom muzeu v Nitre. In: Marketing kulturneho dedicstva $\mathrm{v}$ kontexte konkurencieschopnosti v cestovnom ruchu. Nitra: UKF, pp. 84-94. ISBN 978-80-558-0167-4.

PETRIKOVA, A. 2014. Multimedia Text-Book as a Means of Personality Development during the Process of Teaching the Russian Language. In: Xlinguae, vol. 7, n. 1. ISSN 1337-8384.

PINGEL, F. 2010. UNESCO Guidebook on Textbook Research and Textbook Revision. Paris: UNESCO. ISBN 978-92-3-104141-9.

POKRIVCAKOVA, S. 2010. Modern Teacher of English. Nitra: Aspa. ISBN 978-80-89477-70-4.

REID, E. 2010. Culture - an Inevitable Part of a Foreign Language Teaching. In Modernisation of Teaching Foreign Languages: CLIL, Inclusive and Intercultural Education. Brno: Masaryk University, pp. 199-215. ISBN 97880-210-5294-9.

REID, E. 2012. Development of Intercultural Communicative Competences in Foreign Language Education. In: 15 rokov KLIS PF UKF v Nitre. Nitra: UKF, pp. 191-198. ISBN 978-80-558-0079-0.

REID, E. 2014. Status of Intercultural Education in English Language 244 Learning and in Foreign Language Teacher Training. In: Xlinguae, vol. 7, n. 4. ISSN 1337-8384.

STRADLING, R. 2004. Multiperspectivity in History Teaching: A Guide for Teachers. Strasbourg: Council of Europe. 64 p. [cit. 15.9.2014] Available online:

$<$ http://www.coe.int/t/dg4/education/historyteaching/Source/Notions/Multipe rspectivity/MultiperspectivityEnglish.pdf>

SOLAIMAN, A.M. 2007. Dictionary of Education: Language of Teaching and Learning. Bloomington: AuthorHouse. ISBN 978-1-4208-9278-9.

TRAMPOTA, T. - VOJTECHOVSKA, M. 2010. Metody vyzkumu medii. Praha: Portal. ISBN 978-80-7367-683-4.

WIMMER, R.D. - DOMINICK, J.R. 2011. Mass Media Research. An Introduction. Boston: Wadsworth. ISBN 978-1439082744

UNESCO: Records of the General Conference: Resolutions, $31 \mathrm{C} /$ Resolution 15. Paris: UNESCO, 2002. 181 p. [online] [cit. 30.9.2014] Available online: $<$ http://unesdoc.unesco.org/images/0012/001246/124687e.pdf\#page $=67>$

\section{Researched textbooks}

HARRIS, M. - MOWER, D. - SIKORZYŃSKA, A. 2006. New Opportunities. Pre-Intermediate Students' Book. Harlow: Longman, 145 p. ISBN 0-582-85419-9.

MCKINLAY, S. - HASTINGS, B. 2011. Success. Pre-Intermediate Students' Book. Harlow: Longman, 145 p. ISBN 978-1-405-85192-3. 
CUNNIGHAM, S. - MOOR, P. 2010. Real Life. Pre-Intermediate Students' Book. Pearson Harlow: Pearson Longman, 135 p. ISBN 978-1-4058-9706-8.

Peter Mikuláš, PhD.

Department of Massmedia Communication and Advertising, Faculty of Arts, Constantine the Philosopher University in Nitra

Dražovská 4, 94974 Nitra

Slovakia

pmikulas@ukf.sk

Alena Mikulášová, $\mathrm{PhD}$.

Department of History, Faculty of Arts, Constantine the Philosopher University in Nitra

Hodžova 1,94974 Nitra

Slovakia

amikulasova@ukf.sk 